ISSN (print): 1698-6180. ISSN (online): 1886-7995

www.ucm.es/info/estratig/journal.htm

Journal of Iberian Geology 38 (1) 2012: 253-270

http://dx.doi.org/10.5209/rev_JIGE.2012.v38.n1.39218

\title{
Active tectonics of the Alhama de Murcia fault, Betic Cordillera, Spain
}

\author{
Tectónica activa de la Falla de Alhama de Murcia, Cordillera Bética, España
}

\author{
J.J. Martínez-Díaz* 1,2, E. Masana ${ }^{3}$, M. Ortuño ${ }^{4}$ \\ ${ }^{1}$ Dpto. de Geodinámica, Facultad de Ciencias Geológicas, Universidad Complutense, 28040 Madrid, Spain \\ ${ }^{2}$ Instituto de Geociencias IGEO (UCM-CSIC),28040 Madrid, Spain, jmdiaz@geo.ucm.es \\ ${ }^{3}$ RISKNAT. Dpt. Geodinamica i Geofisica, Facultat de Geologia, Universitat de Barcelona. c/ Marti i Franques s/n. \\ 08028 Barcelona, Spain, Eulalia.masana@ub.edu \\ ${ }^{4}$ Centro de Geociencias, Universidad Nacional Autónoma de México, Blvd. Juriquilla, 3001, 76230 Juriquilla, \\ Querétaro, Mexico.maria_ortuno@geociencias.unam.mx \\ *Corresponding author
}

Received: 24/04/12 / Accepted: 10/05/12

\begin{abstract}
We present an overview of the knowledge of the structure and the seismic behavior of the Alhama de Murcia Fault (AMF). We utilize a fault traces map created from a LIDAR DEM combined with the geodynamic setting, the analysis of the morphology, the distribution of seismicity, the geological information from E 1:50000 geological maps and the available paleoseismic data to describe the recent activity of the AMF. We discuss the importance of uncertainties regarding the structure and kinematics of the AMF applied to the interpretation and spatial correlation of the paleoseismic data. In particular, we discuss the nature of the faults dipping to the SE (antithetic to the main faults of the AMF) in several segments that have been studied in the previous paleoseismic works. A special chapter is dedicated to the analysis of the tectonic source of the Lorca 2011 earthquake that took place in between two large segments of the fault.
\end{abstract}

Keywords: Alhama de Murcia Fault, Betic Cordillera, active faults, slow-moving faults, strike-slip faults.

Resumen

En este estudio se presenta una revisión del conocimiento que hasta la actualidad se tiene de la estructura y comportamiento sismogenético de la Falla de Alhama de Murcia (AMF). Se utiliza un nuevo mapa de la traza de la AMF realizado a partir de un modelo 
digital del terreno de alta resolución a partir de datos LIDAR, combinado con el análisis del marco geodinámico, la geomorforlogía, la distribución espaciotemporal de la sismicidad, la información geológica de trabajos previos y los datos paleosísmicos existentes, para describir la actividad reciente de la AMF. Se discute la importancia de las incertidumbres que se mantienen en relación con la estructura y la cinemática de la AMF para la correcta interpretación y correlación espacio-temporal de los datos paleosísmicos obtenidos hasta ahora. En particular, se discute la naturaleza de las fallas con buzamiento SE en superficie (antitéticas con las fallas principales de la AMF que bordean las sierras) en varios segmentos que han sido estudiados en análisis paleosismológicos previos. Se dedica un capítulo especial al análisis de la fuente geológica del terremoto de Lorca de 2011 que tuvo lugar en la zona de intersegmento que separa dos de los segmentos de mayor longitud de la AMF.

Palabras clave: Falla de Alhama de Murcia, Cordillera Bética, fallas activas, fallas lentas, fallas de desgarre.

\section{Introduction}

The Alhama de Murcia Fault (AMF) (Bousquet et al., 1979 ) is a strike-slip shear zone with reverse component that crosses the eastern Betic cordillera with a NE-SW direction (Fig. 1). The AMF accommodates $\sim 0.1-0.6$ $\mathrm{mm} / \mathrm{yr}$ of the approximately $5 \mathrm{~mm} / \mathrm{yr}$ of convergence between Nubian and Eurasian plates (Masana et al., 2004) and is one of the largest faults of the Eastern Betics Shear Zone (Silva et al., 1993). Many of the largest damaging historical earthquakes occurred in the eastern Betic Cordillera are related to this structure (Fig. 1).

The most damaging earthquake occurred in Spain in the last 50 years took place next to the city of Lorca (11/05 2011, Mw 5.2). In spite of its moderate size this earthquake produced massive damage in this city. This earthquake has been related to the activity of the AMF (i. e. IGME, 2011; Vissers and Meijninger, 2011; LopezComino et al., 2012; Martínez-Díaz et al., 2012). In recent years several studies have focused on the characterization of the paleoseismic activity and the determination of AMF seismic parameters: slip rate, recurrence interval, maximum magnitude (Martínez-Díaz et al., 2001; Masana et al., 2004, 2005, Masana, 2010; Ortuño et al., 2012). All of these parameters were obtained by the study of trenches excavated in sites that were appropriated to identify recent (preferably later Quaternary) surface ruptures. Until now, these studies have been restricted to two of the four segments that form the AMF. The correct interpretation of these data and the correct extrapolation to the whole fault requires a good knowledge of the deep and shallow structure of the fault zone. But this also requires improving our understanding of the relationships between the fault structure, the morphology, and the spatial and temporal evolution of historical and instrumental seismicity. We still have significant limitations in the knowledge of the structure of the AMF that may limit the interpretation of the paleoseismic data. The Lorca earthquake gave us some insights to improve this knowledge.

In this work we present a review of the origin, structure, Miocene evolution, Quaternary activity, morphotectonic implications and seismogenic behavior of the AMF. We present a new AMF fault trace map from a high resolution DEM, and we utilize the geomorphology, the spatial distribution of seismicity, the geological mapping and the available paleoseismic data to describe the detailed geometry of the AMF segments. We interpret the deep structure of the fault that is coherent with the surface geology and we finally discuss the needs to improve our knowledge of the seismogenic behavior of this fault. A special chapter is dedicated to the analysis of the tectonic source of the Lorca 2011 earthquake that took place in between two large segments of the fault.

\section{Geodynamic setting}

The study area is located in the Internal Zones of the Betic Cordillera (Fig. 1), commonly referred to as the A1boran Domain (Balanya and García Dueñas, 1987). This area is composed of Paleozoic, Mesozoic and Paleogene rocks, which developed as a thrust stack during the Alpine Orogen (Egeler and Simon, 1969). The Alboran domain belongs to the formerly Alpine Orogene that was a continuous structure from northwest Africa, along the Betic Cordillera, and to Western Alps during Cretaceous - Neogene. The thrusts bounding the major tectonic complexes (Nevado-filabride, Alpujarride and Malaguide) were later reactivated as low-angle normal faults under regional extensional tectonics (Aldaya et al., 1991; García-Dueñas et al., 1992; Galindo-Zaldívar et al., 1989; Jabaloy et al., 1993). Martínez-Martínez and Azañon (1997) inferred two nearly orthogonal extension episodes from the Burdigalian to the Serravalian. The neotectonic period (the last $9 \mathrm{My}$ ) started after this extensional process, and a compressional stress field with a NNW-SSE shortening direction became dominant. Deformation under this stress field formed high-angle (strike-slip, normal and reverse) faults that have been active since Late Miocene. The Alhama de Murcia Fault is one of these faults.

This NNW-SSE shortening direction is driven by plate tectonics (Fig. 2). The Nubia-Eurasia and Eurasia-North America motions changed significantly approx. $3 \mathrm{Ma}$ 
Fig. 1.- Regional distribution of instrumental and historical seismicity within the Betic Cordillera. A: epicentres of earthquakes from the period 0-2010 with horizontal error of location $<10 \mathrm{~km}$, data from the "Instituto Geográfico Nacional". The AMF is framed by the square. B: Historical earthquakes with intensity EMS > VI. Note the significant alignment of epicenters along the AMF. The structural division of the Betic-Rif Cordillera is shown for reference in the inset.

Fig. 1.- Distribución regional de la sismicidad histórica e instrumental en la cordillera Bética. A: Se muestran los epicentros para el periodo 0-2010 con error de localización epicentral $<10$ $\mathrm{km}$, datos procedentes del Instituto Geográfico Nacional. Se enmarca con un cuadrado la Falla de Alhama de Murcia (AMF). B: Se muestra la sismicidad instrumental con intensidad EMS > VI. Nótese el alineamiento de epicentros a lo largo de la AMF. Se muestra también la división estructural de la cordillera Betico-Rifeña en el recuadro superior izquierdo.

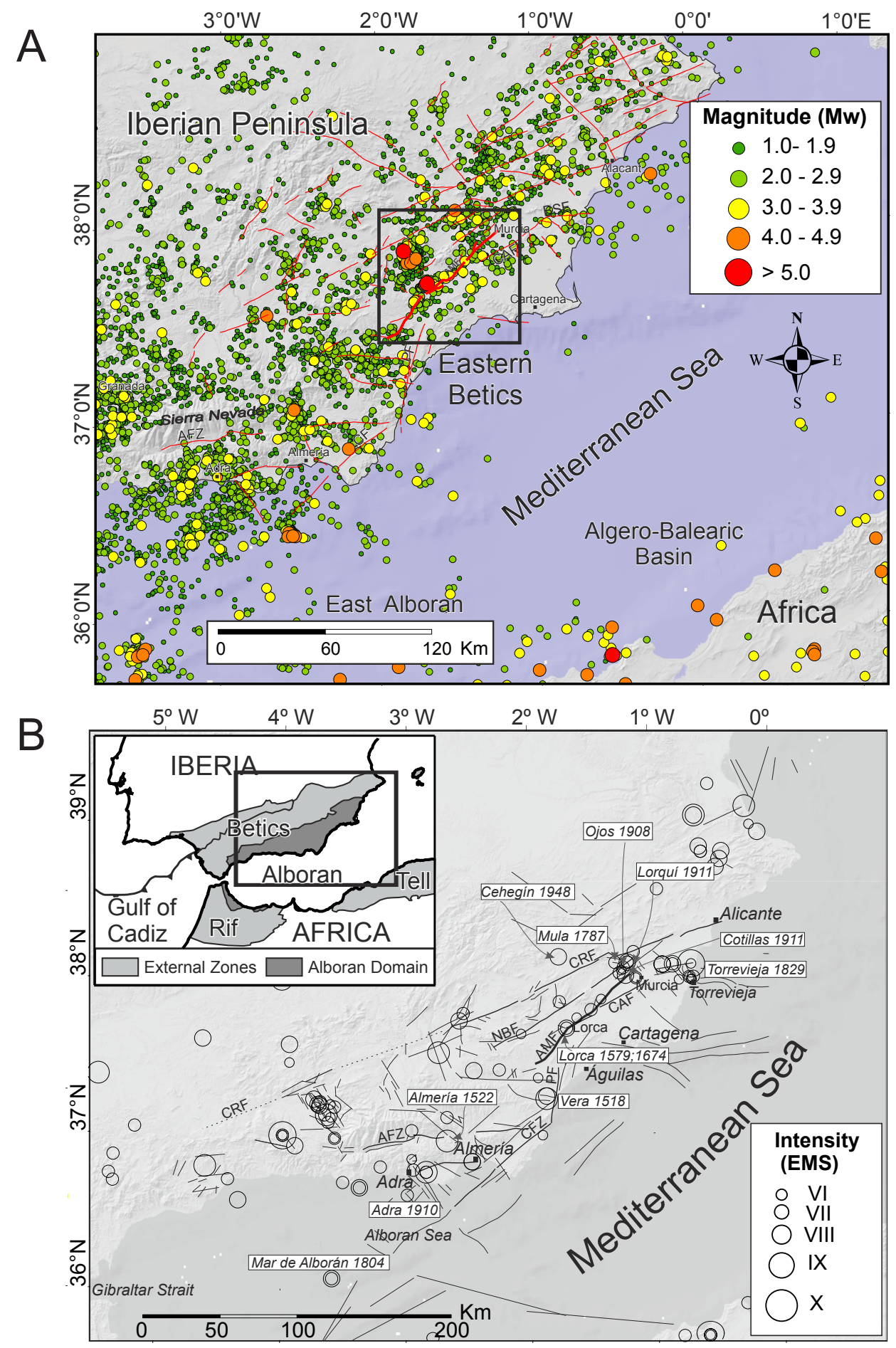

(Calais et al., 2003). These authors combined GPS velocities from the Nubian, Eurasian, and North American plates with 3.16-My-average seafloor spreading rates and nine transform fault azimuths from the northern Atlantic and Arctic basin seafloor spreading centers. The geodetic velocities suggest that the direction of Nubia-Eurasia convergence has rotated roughly $20^{\circ}$ counter-clockwise in the last My along the Mediterranean collision zone, reflecting significant southward migration of the rotation pole during this period. Their model predicts that NU-EU convergence rates have decreased by roughly $25 \%$ in the eastern Mediterranean over the last $3 \mathrm{My}$, with a relative plate motion direction becoming more oblique. This change in the direction of the Nubia-Eurasia plate motion is consistent with the Pliocene to Quaternary counterclockwise rotation of the compression direction inferred for northern Algeria (Meghraoui et al., 1986). Changes in the horizontal shortening direction identified during the Neotectonic period in previous works along the AMF are consistent with this plate motion scenario (Martínez- 


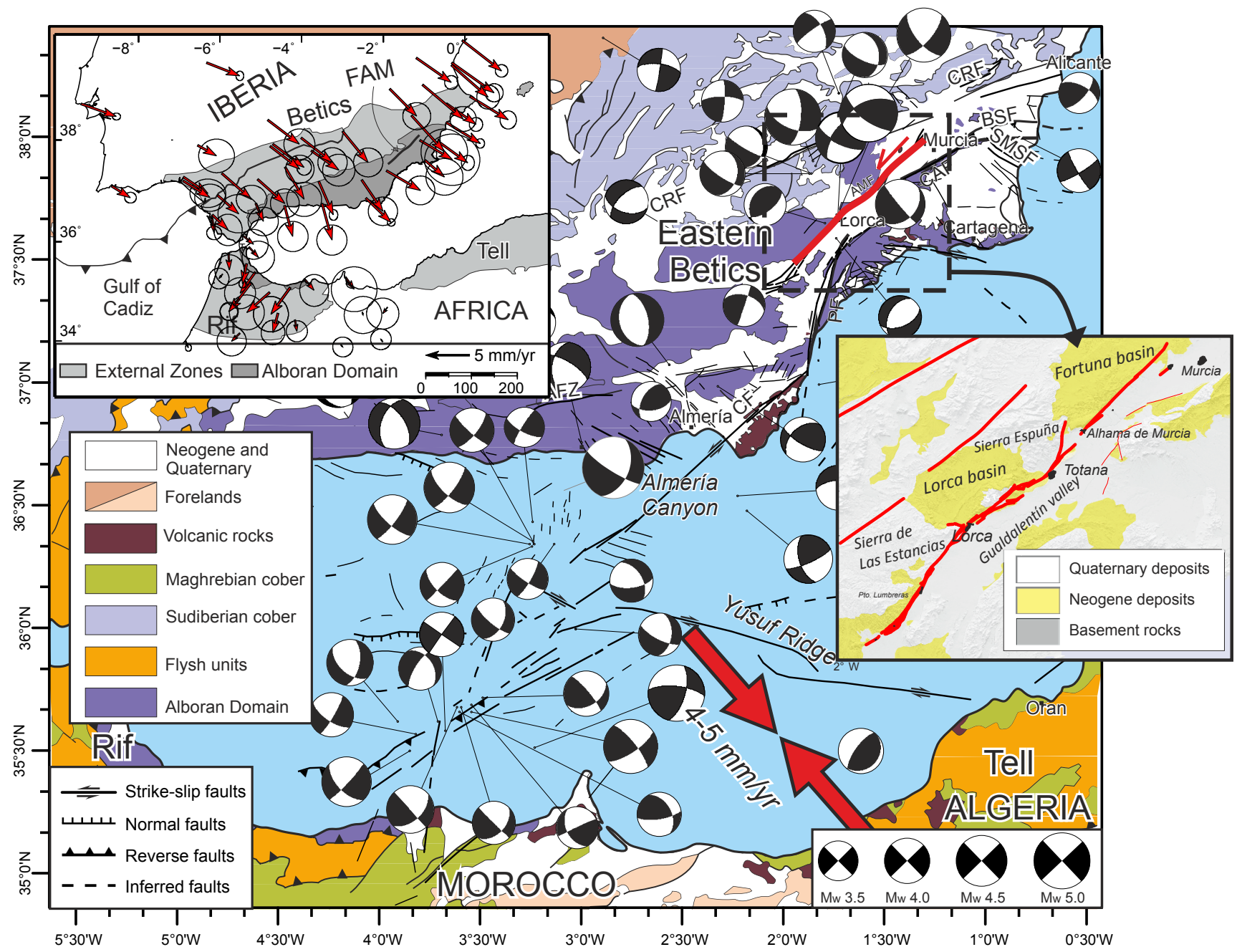

Fig. 2.- Geological map of the Betic cordillera and Alboran Sea with the moment tensor solutions from the "Instituto Andaluz de Geofisica". Upper left inset shows the GPS velocities (considering stable Nubian plate) from Koulali et al. (2011). Right inset: geological sketch of the Alhama de Murcia fault and surrounding region.

Fig. 2.- Mapa geológico de la cordillera Bética y del mar de Alborán con los mecanismos focales procedentes del Instituto Andaluz de Geofísica. Arriba a la izquierda se representan las velocidades GPS tomadas de Koulali et al. (2011), considerando la placa Africana estable. El mapa de la derecha muestra un esquema de la estructura en el entorno de la falla de Alhama de Murcia.

\section{Díaz, 2002).}

The AMF is a left-lateral strike-slip fault since, at least, Upper Miocene (Tortonian) (Montenat et al., 1987). Before that time it was a normal fault that generated an elevated massif along the current Guadalentín depression. The relative sinking of the hanging wall favored the formation of several Neogene basins: Lorca and Fortuna basins (Fig.2b) (Montenat et al., 1987; Silva, 1994; Martínez-Díaz, 1998). Since Tortonian the area undergoes a horizontal shortening direction (Shmax) of $\mathrm{N} 150^{\circ}$. A number of neotectonic studies describe an important reverse component in some sections of the fault (Silva, 1994; Martínez-Díaz, 1998; Meijninger, 2006) consistent with the regional geodynamic setting.

Recently, GPS velocity vectors from stations surrounding the southeastern Betic Cordillera (Fig. 2), as we dis- cuss below, suggest a regional shortening direction nearly orthogonal to the AMF (e.g.: Koulali et al., 2011), which is consistent with the geological observations. The complex neotectonic history of the AMF and its segmented structure must be taken into account to understand its present seismic potential.

\section{Structure and evolution of the AMF}

\subsection{Stress field driving the AMF}

Since the 1970s papers dealing with the tectonic evolution and the structure of the Alhama de Murcia fault have identified a complex spatial and temporal distribution of the stress field along it from the Middle Miocene to the present (Fig. 3). 
The Alhama de Murcia fault (AMF) bounds the Lorca and Alhama-Fortuna Neogene basins (Fig. 2). These basins formed during an extensional phase in the Middle to Late Miocene (e. g.: Montenat et al., 1990). During this time some segments of the AMF (at least the Lorca-Totana and the Alhama-Alcantarilla segments) behaved as normal faults driving the sinking of the basins (MartínezDíaz, 1998). At this time the Guadalentin valley was a positive relief. During the Upper Miocene the regional stress field changed to a NW-SE shortening direction driven by the modern plate tectonic configuration. This change produced a tectonic inversion on the AMF (Martínez-Díaz, 1998).
Spatial and temporal differences in the stress field have been revealed by a number of authors at the AMF and on its surroundings. Bousquet and Phillip (1976b) identified post-Pliocene horizontal shortening directions along the AMF varying from NW - SE to NE - SW. Later, Armijo (1977), based in stress inversion analysis of the Lorca-Totana sector in post-Middle Miocene materials, interpreted extensional structures up to Messinian age followed by compressional structures with a NE-SW to NNE -SSW Shmax direction during the Late Pliocene (Fig. 2). Under this scenario, the AMF moved as a sinistral strike-slip fault. Finally, during the Quaternary, a compressional stress field with NNW-SSE horizontal

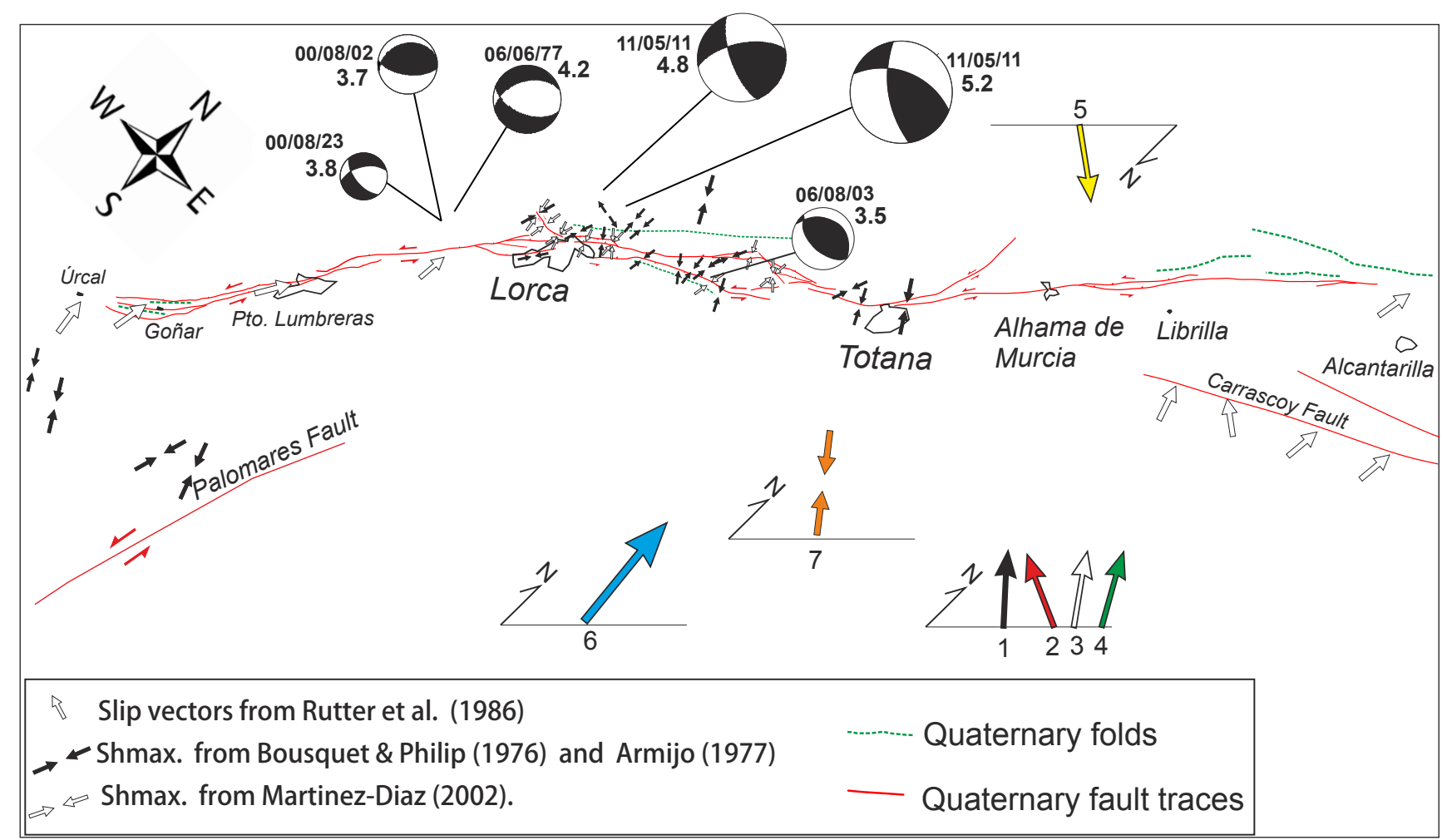

Fig. 3.- Dynamical and kinematical data provided in previous works along the AMF trace combined with GPS velocity vectors and focal mechanisms. Black and white double arrows are the horizontal stress orientations obtained from microtectonic data in Bousquet and Phillip (1976a, b) and Armijo (1977). Single white arrows are horizontal slip vectors obtained from fault gouge analysis by Rutter et al. (1986). Single arrows labeled 1 to 5 are the GPS velocity vectors closest to the AMF extracted from regional models 1: Calais et al. (2003); 2: Serpelloni et al. (2007); 3: DeMets et al. (1994); 4: Jimenez-Munt et al. (2003) (est. Alicante); 5: Koulali et al. (2011) (1 to 4 considering Eurasia stable; 5 considering Nubia plate stable). Arrow 6 is the GPS velocity vector closest to the AMF obtained from the local GPS network CUATENEO (Khazaradze et al., 2008); Arrow 7: is the direction of maximum horizontal compressional stress from the regional modeling of Jimenez-Munt and Negredo (2003). Focal mechanisms from the Instituto Andaluz de Geofísica (http://www. ugr.es/ iag/tensor/) and the Instituto Geográfico Nacional (http://www.01.ign.es/ign/layout/sismo.do).

Fig. 3.- Datos dinámicos y estructurales a lo largo de la falla de Alhama de Murcia extraídos de trabajos previos, combinados con vectores de velocidades GPS y mecanismos focales. Las flechas dobles blancas y negras indican orientaciones del máximo esfuerzo horizontal compresivo obtenidas a partir de datos microtectónicos por Bousquet and Phillip (1976a, b) y Armijo (1977). Las fechas blancas individuales son los vectores de deslizamiento horizontal obtenidos por Rutter et al. (1986) a partir del análisis de la roca de falla de la AMF. Las flechas individuales etiquetadas 1 a 5 representan los vectores de velocidad GPS mas próximas a la AMF extraídas de modelos regionales: 1: Calais et al. (2003); 2: Serpelloni et al. (2007); 3: DeMets et al. (1994); 4: Jimenez-Munt et al. (2003) (est. Alicante); 5: Koulali et al. (2011) (1 a 4 considerando Eurasia estable; 5 considerando la placa Africana estable. La flecha 6 es la velocidad GPS más próxima a la AMF obtenida de la red GPS CUATENEO (Khazaradze et al., 2008); La flecha 7: indica la dirección del máximo esfuerzo compresivo horizontal extraído del modelo regional de Jimenez-Munt y Negredo (2003). Los mecanismos focales proceden del Instituto Geográfico Nacional (http://www.ugr.es/ iag/tensor/) y del Instituto Geográfico Nacional (http://www.01.ign.es/ign/layout/sismo.do). 


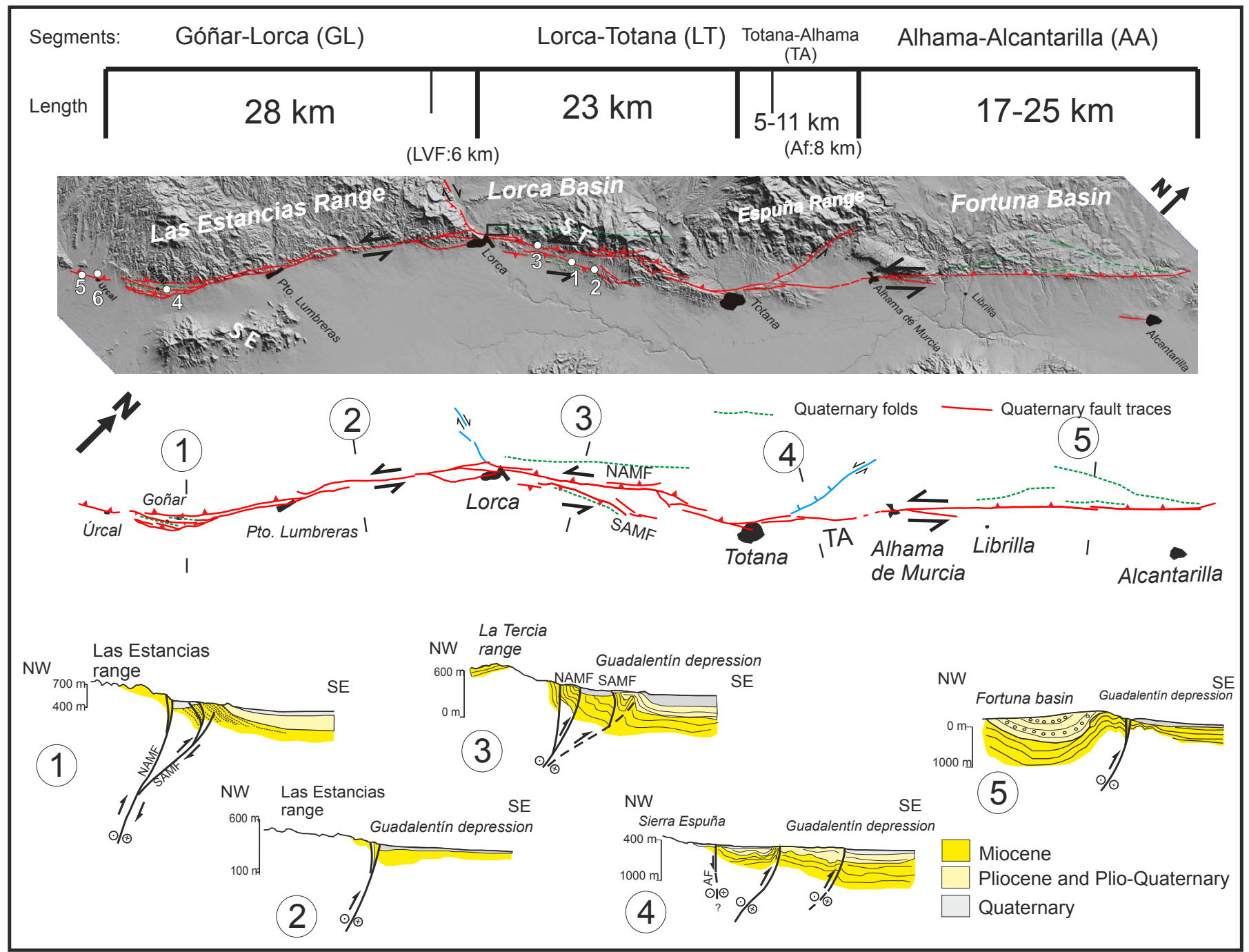

Fig. 4.- Synthesis of the structure and segmentation of the Alhama de Murcia fault from the detailed mapping of the fault trace projected on the LIDAR derived digital elevation model (NATMUR project) (above). The geological cross sections were built from 1:50,000 geological maps of the Instituto Geológico y Minero de España (IGME). In blue we mark the two main secondary faults that interact with the AMF, Las Viñas fault (LVF) and Amarguillo Fault (AmF). ST: La Tercia range; SE: Enmedio range. The numbers 1 to 6 on the digital elevation model indicate the situation of the paleoseismological sites described in the text. 1: Saltador; 2: Colmenar; 3: Carraclaca; 4: Goñar; 5: Ruchete; 6: Urcal.

Fig. 4.- Síntesis de la estructura y la segmentación de la Falla de Alhama de Murcia a partir de la cartografía detallada de la traza de la falla proyectada sobre el modelo digital del terreno derivado de datos LIDAR (Proyecto NATMUR) (arriba). Los cortes geológicos se realizaron utilizando la información geológica del mapa 1:50.000 del Instituto Geológico y Minero de España (IGME). En azul se marcan las dos fallas secundarias principales que interaccionan con la AMF, falla de Las Viñas Fault (LVF) y la falla de Amarguillo (AmF). ST: Sierra de la Tercia; SE: Sierra de En medio. Los números 1 a 6 sobre el modelo digital marcan la localización de los lugares de análisis paleosísmico realizados en trabajos previos y que son descritos en el texto, 1: Saltador; 2: Colmenar; 3: Carraclaca; 4: Goñar; 5: Ruchete; 6: Úrcal.

shortening was suggested to induce an increase in the reverse component of the slip. Armijo (1977) identified this dual mode in the horizontal shortening direction by the analysis of macro and microstructures in the interior of the Lorca-Totana corridor.

Other studies at AMF and nearby Neogene basins (Bousquet and Phillip, 1976a,b; Montenat et al., 1987, 1990; Ott d'Estevou and Montenat, 1985) interpreted paleostress field evolution with two rotations in the Shmax direction between NNW - SSE and NNE- SSW.
These rotations were inferred to result in changes in the type of movement of major and minor faults. All of these studies were based on the correlation of data at local outcrop scale and led to progressively more complicate interpretations of the neotectonic development of the AMF, such as the proposal of deformational phases taking place since Upper Miocene. Martínez-Díaz (2002), however, suggests that the different kinematics of the Lorca - Totana sector of the AMF, within this period, could also be explained in terms of a single stress field. Processes of: 
(1) dynamic interaction between nearby faults; (2) different motion of blocks in the horizontal plane; (3) different uplift rates in the hanging wall; (4) surface flexure that induces local extension; (5) constrained motion of fault bounded blocks; and (6) the "porpoising effect" (c.f.: Crowell and Sylvester, 1979) related to local changes in the fault direction can explain the occurrence of local stress fields of lower spatial hierarchy, all consistent with a single and constant NNW - SSE maximum horizontal compressive regional stress field since the Upper Miocene.

In the AMF horizontal shortening directions and slip vectors on the fault plane within the Neotectonic period published in previous works (black and white double arrows and white single arrows on Fig. 3) are consistent with strike-slip and oblique-slip (reverse-sinistral) movements. The reverse component is more evident in the sections of the fault oriented ENE-WSW than in the sections oriented NNE-SSW (Lorca-Totana segment and in the SW termination of the fault, Goñar area). Available focal mechanisms confirm the importance of the reverse movement, specially the focal mechanism of the 11/05/2011 Mw 5.2 Lorca earthquake (Fig. 3). This earthquake is clearly related with the reactivation of a patch of the AMF close to Lorca and the best focal solution gives a slip vector with a rake of $44^{\circ}$.

Recent new GPS velocities available in the western Mediterranean have led to a number of new kinematic models. In figure 3 we show some of the velocity vectors calculated in these regional models for the AMF region (arrows labeled 1 to 6 ) and a local velocity vector from the local GPS network CUATENEO (arrow labeled 7). Most of the GPS velocity orientations are consistent with a horizontal shortening that is oriented at $40^{\circ}$ to $90^{\circ}$ to the AMF (depending on the orientation of each segment). The orientation of the local velocity from Khazaradze et al. 2008 (oriented $40^{\circ}$ to $60^{\circ}$ to the fault) is the more consistent with the kinematic geological data and focal mechanisms. GPS velocity vectors from regional models (oriented $65^{\circ}$ to $90^{\circ}$ to the fault) are less consistent with the strike slip movement. The most compressive horizontal principal stress direction from the regional modeling of Jimenez-Munt and Negredo (2003) (arrow 7 in Fig.3) agrees with a reverse movement of the AMF.

\subsection{Structure of the AMF}

We used a $5 \mathrm{~m}$ resolution digital elevation model derived from LIDAR data to map in detail the AMF (Fig. 4). The trace of the AMF presents a clear surface expression from Urcal in the SW tip to the Segura river valley to the NE, with a total length of $87 \mathrm{~km}$. Gauyau et al. (1977) using gravimetric modeling traced the AMF in the basement over $30 \mathrm{~km}$ from the Segura valley to the Northeast, reaching the Crevillente Fault. However, there are no structural or morphologic evidences of recent activity in that section of the fault. The AMF as a neotectonic structure is considered to end near Alcantarilla where its activity is transferred to the Carrascoy fault, located to the south parallel to the AMF (Martínez-Díaz, 2002; Insua-Arevalo et al., 2012). The southern end of the AMF is defined by the Goñar fault array (Ortuño, 2012) and farther west the deformation is transferred to the Albox fault (Masana et al., 2005).

The width of the shear zone of the AMF varies along segments. The higher width is observed in the SW end (Goñar system) and in the Lorca-Totana section. The principal slip concentrates on a maximum of three branches, and in some sections (Puerto Lumbreras-Lorca) and (Alhama-Alcantarilla) the slip is concentrated on a major fault.

Based on their geometry, fractal signature, and seismicity, Silva et al. (1992a) proposed the subdivision of the fault into four segments: Huercal Overa-Lorca (NNESSW), Lorca-Alhama (NE-SW), Alhama-Alcantarilla (NNE-SSW), and from Alcantarilla to the north. Martínez-Díaz (1999) suggests a subdivision of the LorcaAlhama part into two segments and did not consider the fault to the north of Alcantarilla. In this work we present a refined segmentation taking advantage of the high resolution of the digital elevation model that permits a more detailed mapping of the fault trace (Fig. 4). Based on the geometry of the fault zone, the morphology, the seismicity, and the relief of the hanging wall, we consider four structural segments from south to north: (1) Góñar-Lorca (GL) $(28 \mathrm{~km})$, with a horse tail termination, moderate concentration of epicenters and the evident relief of the Las Estancias Range, (2) Lorca-Totana (LT) (23 km) where the fault is currently bounding the Neogene Lorca basin and controlling the growing of the La Tercia Range. The fault shows the maximum concentration of seismicity along this segment. The Lorca Mw 5.2 2011 earthquake occurred in the SW end of this segment (Martínez-Díaz et al., 2012), (3) Totana-Alhama de Murcia (TA) (5-11 $\mathrm{km}$ ), and (4) Alhama de Murcia-Alcantarilla (AA) (17-25 $\mathrm{km}$ ) which controlled the evolution of the Fortuna basin to the NW but shows low geomorphologic fault expression. At Totana and Alhama de Murcia the structure of the fault is not clear and some possible fault overlapping is observed. This is the reason of the variation in length proposed for TA and AA segments. 


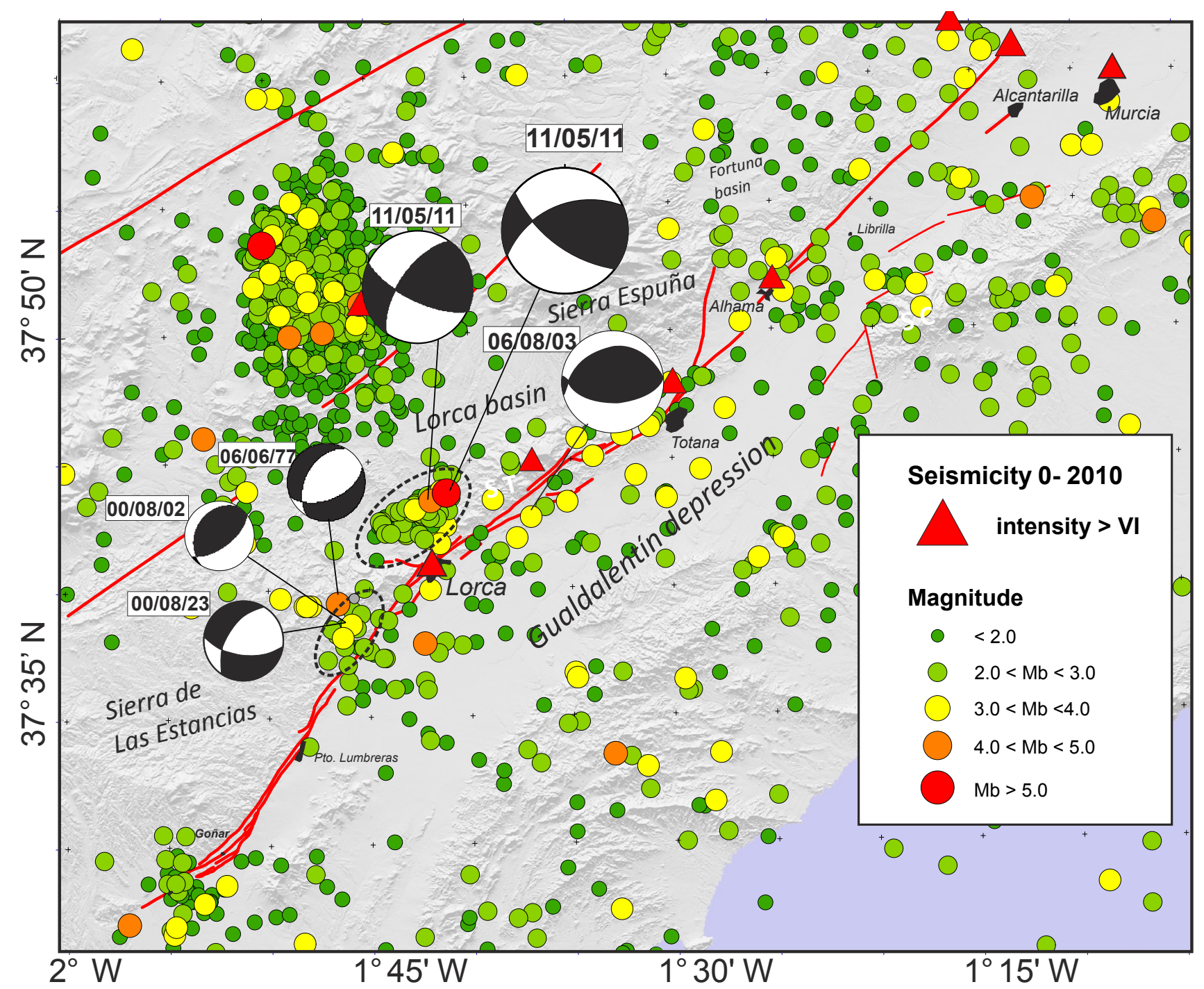

Fig. 5: Map of the seismicity around the Alhama de Murcia Fault. Circles represent the instrumental seismicity for the period 0-2010. Triangles are the epicentres of historical seismicity with intensity $>$ VI. Focal mechanisms of the principal seismic sequences are projected. The seismic data comes from Instituto Geografíco Nacional and the Instituto Andaluz de Geofisica. AMF: Alhama de Murcia Fault CRF: Crevillente Fault, BSF: Bajo Segura Fault, CF: Carrascoy Fault, LTF: Los Tollos Fault, CNF: Cañaricos Fault, MF: Moreras Fault, PF: Palomares Fault, LVF: Las Viñas Fault, AF: Amarguillo Fault, ER: Espuña Range, LTR: La Tercia Range, CR: Carrascoy Range.

Fig. 5.- Mapa de la sismicidad del entorno de la falla de Alhama de Murcia. Los círculos representan la sismicidad instrumental para el periodo 0-2010. Los triángulos representan los epicentros de la sismicidad histórica con intensidad > VI. También se proyectan los principales mecanismos focales de las secuencias sísmicas más importantes. Los datos sísmicos proceden del Instituto Geografíco Nacional y del Instituto Andaluz de Geofisica. AMF: falla de Alhama de Murcia CRF: Falla de Crevillente, BSF: falla del Bajo Segura, CF: falla de Carrascoy, LTF: falla de Los Tollos, CNF: falla de Cañaricos, MF: Falla de las Moreras, PF: Falla de Palomares, LVF: falla de Las Viñas, AF: falla de Amarguillo, ER: sierra de Espuña, LTR: sierra de La Tercia, CR: sierra de Carrascoy.

The direction of the main fault zone changes from $\mathrm{N} 50^{\circ}$ at the SW end to $\mathrm{N} 38^{\circ}$ at the GL segment, $\mathrm{N} 60^{\circ}$ at the LT segment, and finally $\mathrm{N} 47^{\circ}$ at TA and AA segments. The changes at GL-LT and LT-TA transitions match with the intersection of two secondary dip slip faults, Las Viñas fault (LVF) and Amarguillo fault (AF). Quaternary folds parallel to the fault occur in the segments of the AMF with higher angles with Shmax direction.

Five geological cross sections were made using geological data from the 1:50.000 geological maps of the
"Instituto Geológico y Minero" and from Martínez-Díaz (2002) (Fig. 4). The dip of the main faults of the AMF is fairly uniform along the segments, ranging from $60^{\circ}$ to $70^{\circ} \mathrm{NW}$. The focal mechanisms of the recent Lorca 2011 earthquake indicate a plane dipping $55^{\circ}-60^{\circ}$, consistent with the geological observations. The reverse component of movement folds and raises several ranges: La Tercia, Espuña and Las Estancias. However, in the segments with the higher angle to Shmax direction (GL and LT) the AMF branches show several antithetic (dipping toward the de- 
pression) faults. These other faults raise blocks within the depression that captured recent fluvial deposits creating suitable areas for paleoseismic analysis. In fact, paleoseismic excavations carried out so far in the area were done in these antithetic faults: the South AMF (SAMF) at the LT segment and Goñar faults at the end of the GL segment.

A key issue to understand the structure of the fault system is whether these antithetic faults are new and recently formed faults not connected at depth with the main fault of the AMF or, on the contrary, they are shallow structures that accommodate the movement of deeper NW dipping faults (Fig. 4).

\section{Seismotectonics: instrumental and historical seismicity}

The historical seismic catalog contains references to more than ten EMS I $>$ IV earthquakes spatially associated to the AMF, seven with intensity EMS VII (Lorca 1579, 1818; Alhama 1855; Huercal Overa 1863; Lorquí 1930;
Fortuna 1944; Murcia, 1743) and three of intensity EMS VIII: Lorca, 1674, Lorquí 1911(two mainshocks) (Fig. 5). Most of the seismicity is concentrated along the central part of the fault (mainly along the LT segment), and no historical seismicity has been recorded in the southern sector (Goñar-Lorca). In the Lorca-Totana segment the 1579 (EMS I=VIII) and 1674 (EMS I=VIII) earthquakes have the epicenter in Lorca. The last one was compound by a series of at least three large earthquakes, two of them of EMS I=VII and the strongest one of $\mathrm{I}=\mathrm{VIII}$.

The largest instrumental earthquake recorded close to the AMF is the $2011 \mathrm{Mw} 5.2$ Lorca earthquake that caused extensive damage in the city of Lorca (see below). The damage associated with this event was large but limited to this city. The wider extension of the damages associated with the intensity EMS VIII historical earthquakes points to magnitudes probably larger than 5.5 for these events.

Before the 2011 Lorca earthquake only two instrumental seismic sequences of magnitude $\mathrm{Mw} \sim 4.0$ or greater occurred near the AMF producing minor damages: the

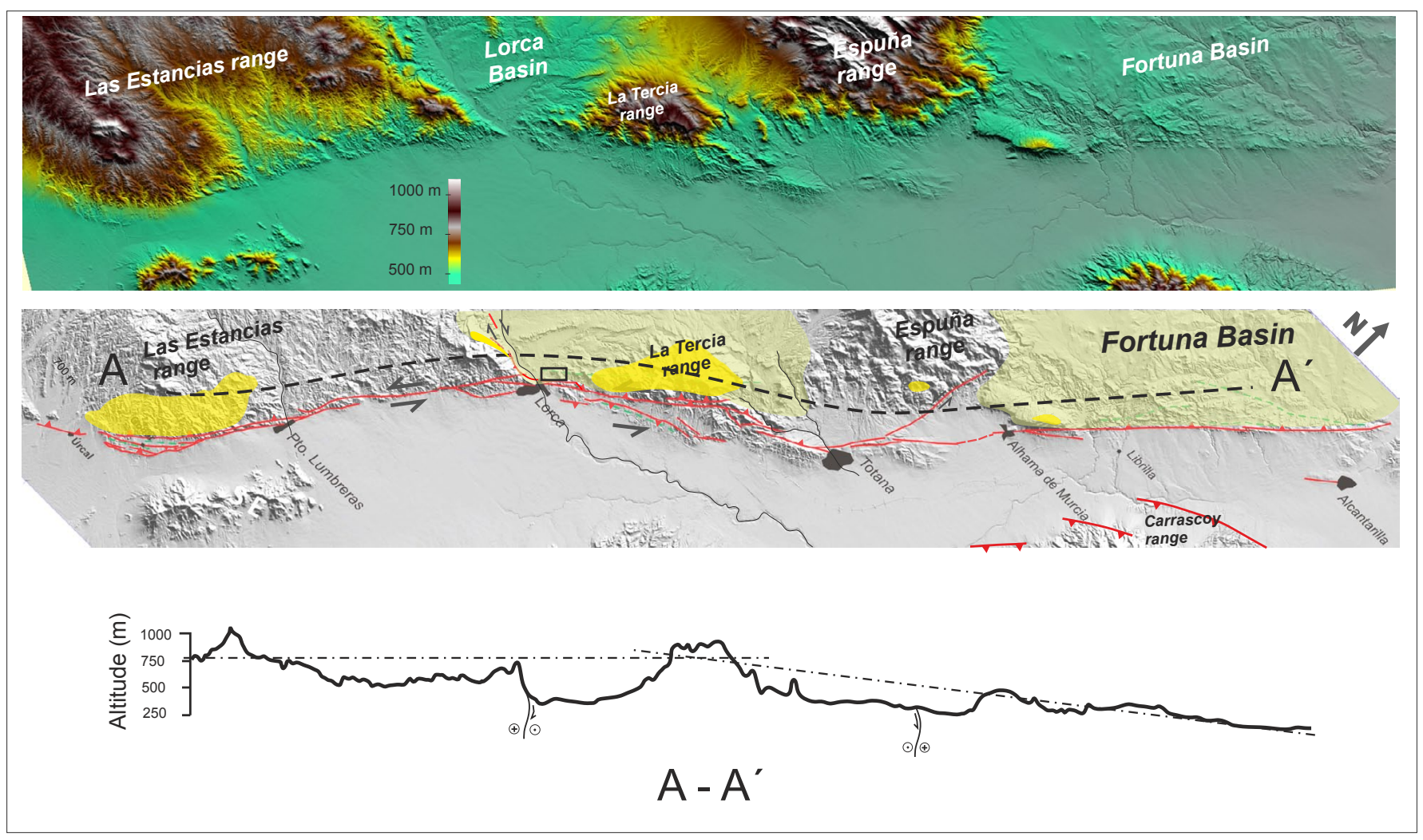

Fig. 6.- Relief of the area surrounding the Alhama de Murcia fault. The ligth yellow mark the present extent of the sediments of the Neogene basins of Lorca and Fortuna. Dark yellow shows areas where late miocene materials reach the highest altitudes in the hanging wall. The dashed line represent the position of the topographic profile A-A'. The rectangle next to Lorca represents the projection of the rupture plane that slipped during the Lorca 2011 earthquake.

Fig. 6.- Relieve del entorno de la falla de Alhama de Murcia fault. En sombreado amarillo claro se marca la extensión actual de los materiales de relleno de las cuencas sedimentarias neógenas de Lorca y Fortuna. En amarillo más osculo se marcan las áreas donde los sedimentos miocenos alcanzan mayor altura en el bloque superior de la AMF. La linea intermitente indica la posición del perfil topográfico A-A'. El rectángulo junto a Lorca representa la proyección del plano de ruptura que deslizó durante el terremoto de Lorca de 2011. 


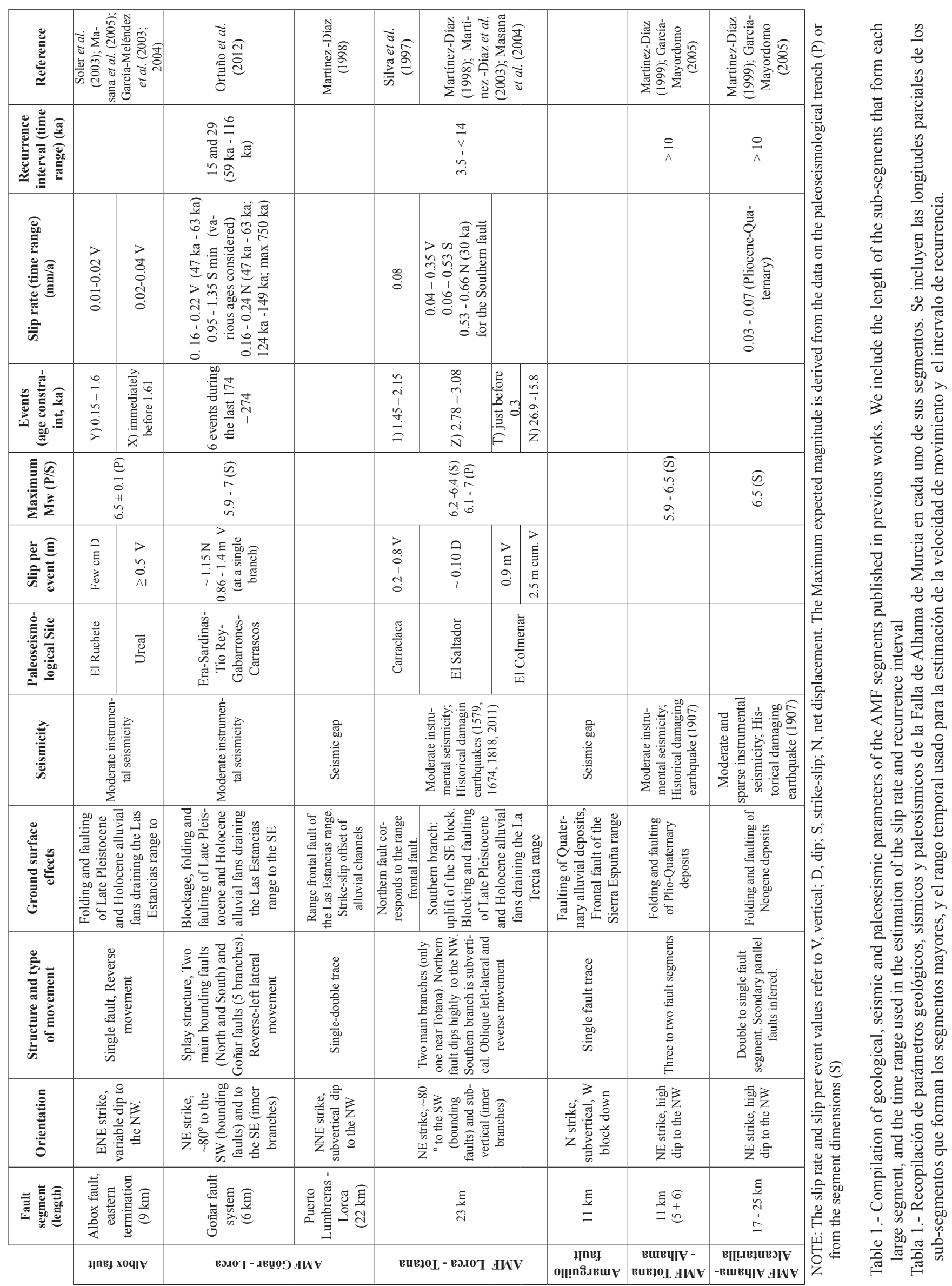




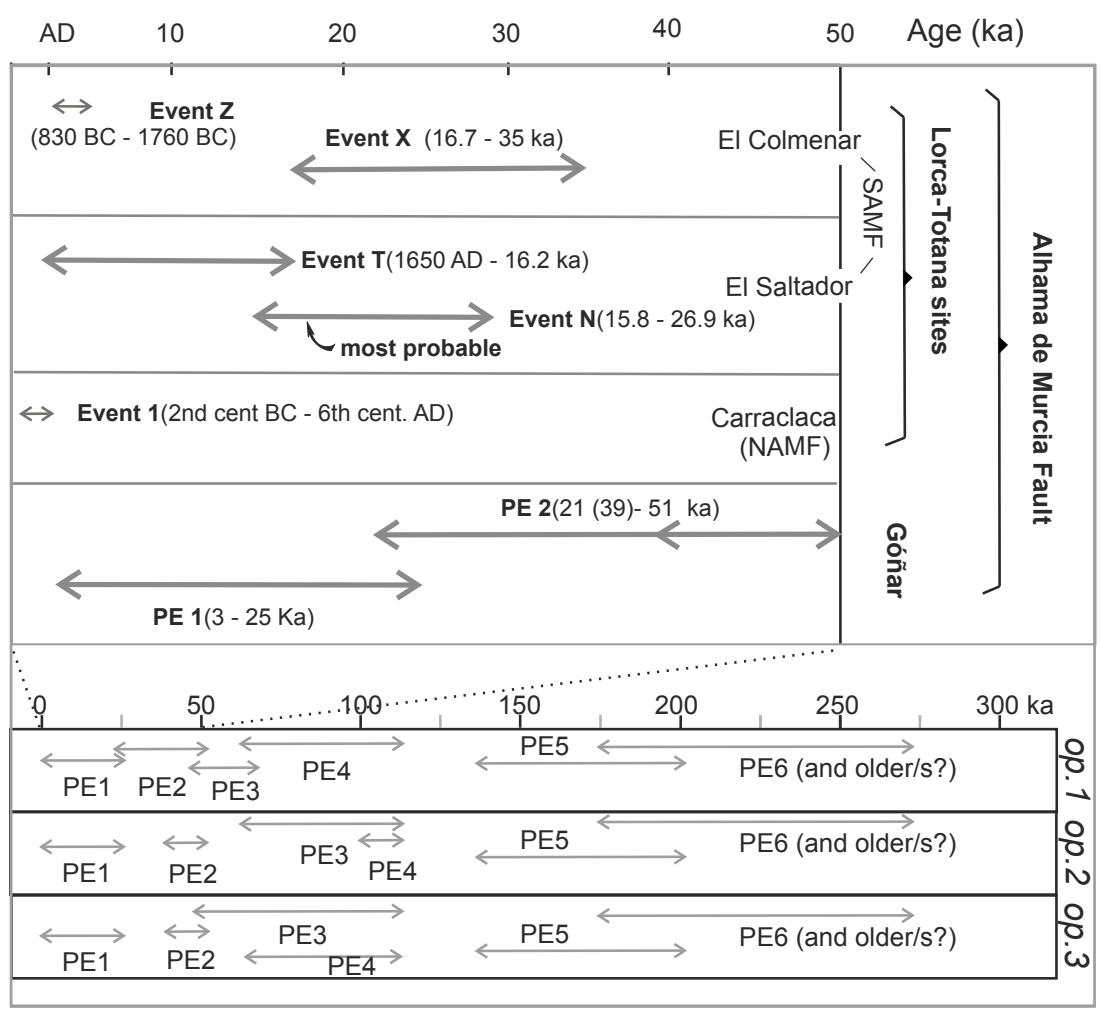

Fig. 7.- Graph showing the recurrence of the paleoearthquakes identified and dated in the previous analysis carried out on the paleoseismological sites shown in figure 4 . The time record covers $300 \mathrm{Ka}$. Three options of interpretation of the recurrence are showed below. For a further discussion of data and local interpretations see Ortuño et al. (2012).

Fig. 7.- Gráfico mostrando la recurrencia de paleoterremotos identificados y dataos en estudios previos realizados en los puntos de análisis paleosísmico señalados en la figura 4.El registro temporal abarca $300 \mathrm{Ka}$. Tres opciones de interpretación de la recurrencia se muestran en la parte inferior. Para una discusión más amplia de los datos y las interpretaciones locales ver Ortuño et al. (2012).

June $1977 \mathrm{Mb} 4.2$ and the August 2000 series with two mainshocks: the mb 3.7 ( $2^{\text {nd }}$ August $)$ and the $m b 3.8\left(23^{\text {th }}\right.$ August) earthquakes. These small earthquakes present focal mechanisms with reverse, normal and oblique slip kinematics (Herráiz and Mezcua, 1979; Martínez-Díaz et al., 2002; Stich et al., 2003) (Fig. 5). This kinematic variability and the location of epicentres and aftershocks have been interpreted as caused by the activation of secondary faults in the hanging wall (Martínez-Díaz et al., 2002).

The distribution of the background seismicity is scattered along the Lorca-Totana, Totana-Alhama and Alhama-Alcantarilla segments. However, there is a significant gap of activity in the Goñar-Lorca segment seismicity (Silva et al. 1997; Martínez-Díaz, 1998 and Masana et al., 2004). The gap is very clear from Góñar to the area where the August 2000 sequence took place, between Puerto Lumbreras and Lorca (Fig. 5). Several studies have shown that the fault rock at the principal displacement zone of the central and northern sector of the GL segment is mainly composed by a more than $10 \mathrm{~m}$ thick clay rich "fault gouge" (Rutter et al., 1986; Rodríguez-Escudero et al. 2012). Similar fault rocks in some segments of large crustal strike slip faults as the San Andreas Fault and the Palomares Fault have been related to rheological behavior dominated by aseismic creep (Faulkner, 1997).

\section{Quaternary activity}

\subsection{Morphology associated to the AMF}

The AMF limits the Guadalentín basin giving rise to the development of prominent mountain fronts along their different segments as initially defined by Silva et al. (1992b) and quantified by Silva et al. (2003). The AMF produces three main mountain fronts, the Sierra de Las Estancias, the Lorca-Totana (La Tercia range) front and the Fortuna basin front (Fig. 6). The first two mountain fronts are developed in metamorphic Paleozoic rocks and in terrigenous and marly sediments of the Neogene Lorca basin. Only the Alcantarilla front is entirely developed in Neogene erodible materials (Silva et al., 2003).

Alluvial fan systems controlled by these fronts have been analyzed in previous works (e.g.: Harvey, 1990; Silva et al., 1992b). Most of them are formed by proximally trenched fans, and dominated by active distal aggradation. In most of the cases, fan channels are disconnected from the base-level controlled axial drainage systems constituted by the Guadalentín River (Silva et al., 1993). These authors, after an extensive quantitative analysis using different geomorphic indexes (Smf and Vf) conclude that the mountain fronts of Las Estancias and Lorca-Totana ranges can be assigned to tectonic class 1 (Bull and McFadden, 1977) consistent with uplift rates of 0.04 to $0.08 \mathrm{~mm} / \mathrm{yr}$. The front of the Fortuna Basin is classified 
by these authors as class 2 with lower activity rate.

The topographic height of recent deposits in the hanging wall of the AMF and the quantitative morphological analysis are consistent with the structure of the AMF and with the long term neotectonic activity of the fault. Figure 6 shows in dark yellow the areas of the hanging wall close to the fault where the late Miocene deposits reach at least $600 \mathrm{~m}$ of altitude. These areas are related with the sectors of higher topography near the fault trace. These higher areas are located in restraining bends of the fault.

The regional gradient of the topography with a gradual decrease of altitude to the east (Fig. 6) is also consistent with a decrease of fault activity. From Totana to the east the slip of the AMF is transferred to the Carrascoy fault system producing the uplift of the Carrascoy range.

\subsection{Paleoearthquake history}

The paleoseismic history of the AMF is among the most studied of the Iberian Peninsula. Four paleoseismological locations have been investigated along its central-southern trace and at the western continuation of the structure, the Albox fault. These sites are, from north to south (Fig. 4): 1) El Saltador (2 trenches) and El Colmenar (2 trenches) sites, along the SAMF 8-9 km northeast of Lorca (Martínez-Díaz et al., 2001; Masana et al., 2004); 2) Carraclaca site (natural outcrop), along the NAMF $\sim 5 \mathrm{~km}$ northeast of Lorca (Silva et al., 1997); 3) Góñar site ( 6 trenches) at the southern termination of the AMF (Ortuño et al., 2012) and 4) El Ruchete (3 trenches) and Urcal (1 trench) sites, at the Albox fault eastern end (Masana et al., 2005). Table 1 and figure 7 summarize the main results derived from the paleoseismological study of these sites. These studies have revealed the earthquake chronology of the last $\sim 40 \mathrm{ky}$. The Góñar site has allowed studying a much longer record (last $\sim 300 \mathrm{ky}$ ). With the exception of Carraclaca, in which only one historical earthquake (between $2^{\text {nd }} \mathrm{c}$. BC and $6^{\text {th }} \mathrm{c}$. AD) has been identified, all the paleoseismological sites have permitted to recognize the occurrence of at least 2 events during the last 40-50 ky. The simultaneity of these events along the different fault traces has been discarded by Ortuño et al. (2012), who have considered that the seismogenic rupture of such a long segment would have resulted in fault displacements much larger than the observed ones $(<1.5 \mathrm{~m})$. These authors, however, have considered as feasible the coseismic rupture of the fault traces from Góñar to El Colmenar-El Saltador based on the observed displacement and the paleoearthquakes chronologies. Such an event would imply surface ruptures of at least $40 \mathrm{~km}$ (relatable with up to $7 \mathrm{Mw}$ earthquakes) and could have occurred twice in the last $40 \mathrm{ky}$ : first in a time pe- riod between 16.7 and $26.9 \mathrm{ka}$, but probably immediately before $16.7 \mathrm{ka}$, and later on between 2.8 and $3.8 \mathrm{ka}$. The paleoseismic study of the AMF southern termination at Góñar, has shown that at least 6 events of Mw (6-7) have occurred in the last $174-274 \mathrm{ky}$. The time range of such events could fit in any of the three options summarized in figure 7.

The different studies referred here suggest that the maximum value of the recurrence period for large $\mathrm{Mw}$ $>6.0$ earthquakes on the AMF ranges between 13 and 24 ky for the central segment and 15 and $29 \mathrm{ky}$ for the fault southern termination.

In table 1 we compile the parameters of activity for each segment of the AMF that have been published in previous works. This table includes the parameters obtained from paleoseismic analysis but also those obtained from long term neotectonic slip rates and from empirical laws relating fault length, maximum magnitude and slip rate (Wells and Coopersmith, 1994). Values of maximum earthquake magnitude and long-term slip rate estimates for the Plio-Quaternary using geological mapping data are also shown. Mw values obtained from the paleoseismicity are consistent with the theoretical $\mathrm{Mw}$ obtained from the segment sizes. However, values of vertical slip rate obtained from the paleoseismicity are lower than those obtained from long-term geological data. The difficulty to know the net slip rate, including the horizontal component of movement, makes difficult to compare these different sets of data. More detailed paleoseismic studies with $3 \mathrm{D}$ analysis are required in order to discuss if these slip rate differences can be explained in terms of incompleteness the paloeoseismic record because of the distribution of deformation in several branches not yet studied or in terms of changes in the activity of the AMF during the Quaternary.

\section{The Lorca 2011 earthquake: implications in the AMF seismic segmentation}

On May 11 2011 an Mw 5.2 earthquake stroke the city of Lorca in south-eastern Spain. This earthquake occurred 2 hours after a Mw 4.1 foreshock and caused 9 fatalities, 300 injuries, serious damage on 1164 buildings and economic losses estimated at more than $1200 \mathrm{M} €$ (data from the Municipality of Lorca). The Lorca earthquake is especially interesting because it took place in the intersegment zone located between Goñar-Lorca and Lorca-Totana segments (Fig. 8). A field survey conducted in the epicentral area 2 days after the earthquake concluded that there was no surface rupture related to this earthquake (IGN, 2011). A detailed mapping of the recent structures on the epicentral area was carried out to un- 

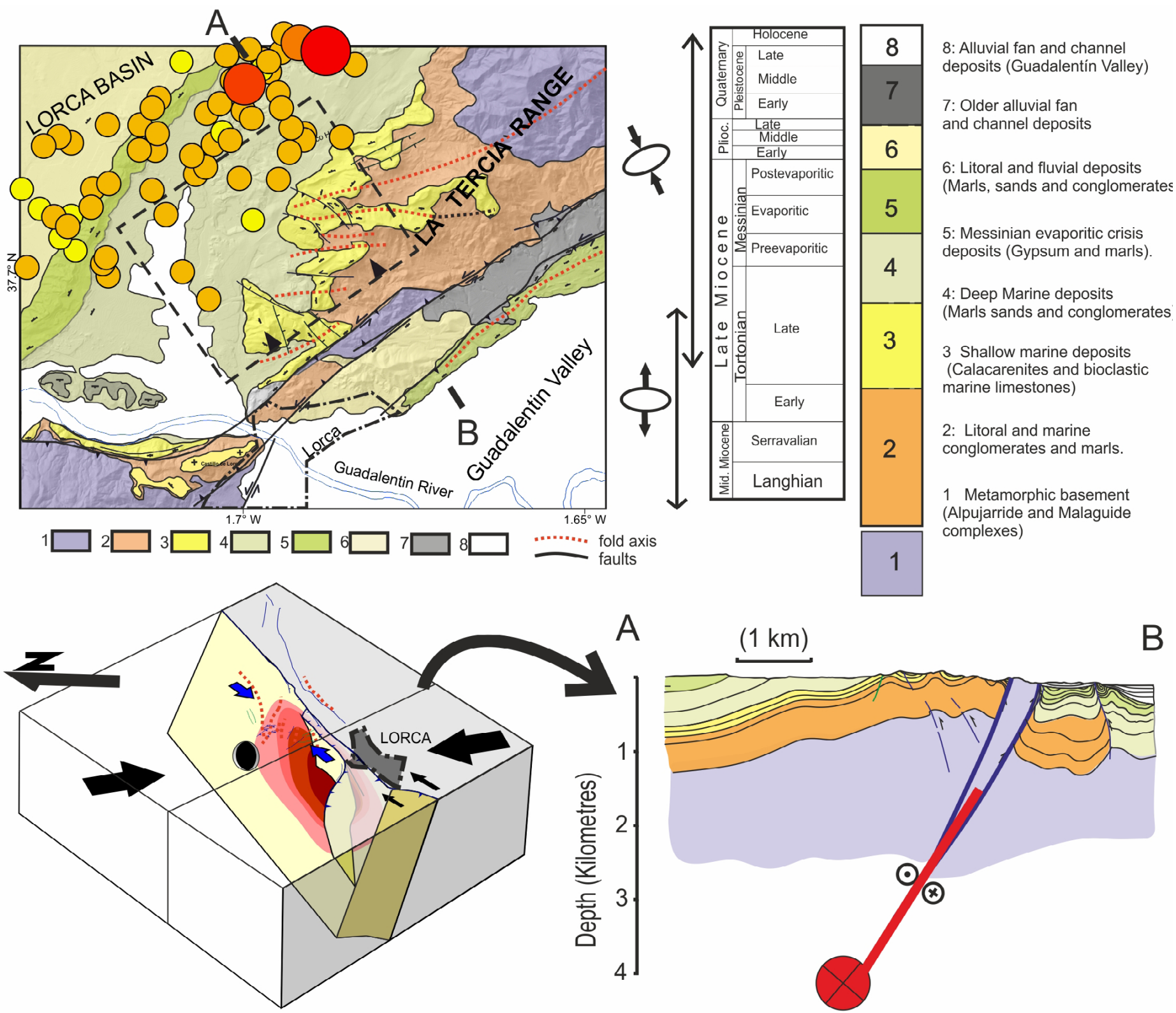

A

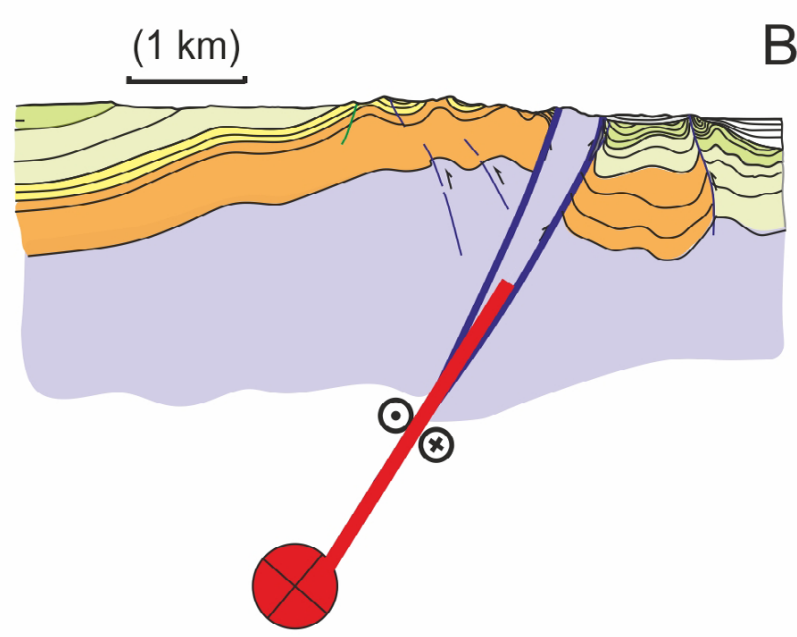

Fig. 8.- Above: geological map of the epicentral area of the Lorca $2011 \mathrm{Mw} 5.2$ earthquake. The aftershocks (orange circles) and the mainshock (large red circle) relocated by Lopez-Comino et al. (2012) are projected. The dashed square in the map is the projection of the rupture on the fault plane modeled by Martínez-Díaz et al. (2012) using RADAR interferometry. The block diagram shows the tectonic model proposed by these authors to explain the origin of the earthquake. A geological cross section transversal to the epicentral area shows the hypocentre and the fault section that slipped during the earthquake (red thick line).

Fig. 8.- Arriba se muestra el mapa geológico de la zona epicentral del terremoto de Lorca de 2011 Mw 5.2. Sobre él se proyectan las réplicas (círculos naranjas) y el evento principal (círculo rojo grande) relocalizados por Lopez-Comino et al. (2012). El recuadro sobre en el mapa representa la proyección sobre la horizontal de la ruptura sobre el plano de falla modelizado por Martínez-Díaz et al. (2012) utilizando interferometría de RADAR INSAR. El bloque diagrama muestra un modelo tectónico propuesto por estos autores para explicar el origen del terremoto de Lorca. El corte geológico transversal a la falla a lo largo de la zona epicentral muestra el hipocentro del terremoto y la sección de la falla que deslizó durante el sismo (línea roja gruesa).

derstand the kinematics of the structures in the intersegment zone and to assess the potential source for the Lorca earthquake (Fig. 8). In this area the AMF undergoes a change of direction from $\mathrm{N} 55^{\circ}$ to the northeast, to $\mathrm{N} 35^{\circ}$ to the southwest. The structure of the fault has a branched geometry in this area due to the existence of contractional strike-slip duplex structures (Martínez-Díaz, 2002) and the interaction with the Las Viñas Fault to the north of Lorca. This interaction produces a contracting slice raised by the movement of the AMF that causes the uplift of the NE corner of the Las Estancias Range (Fig. 8). 


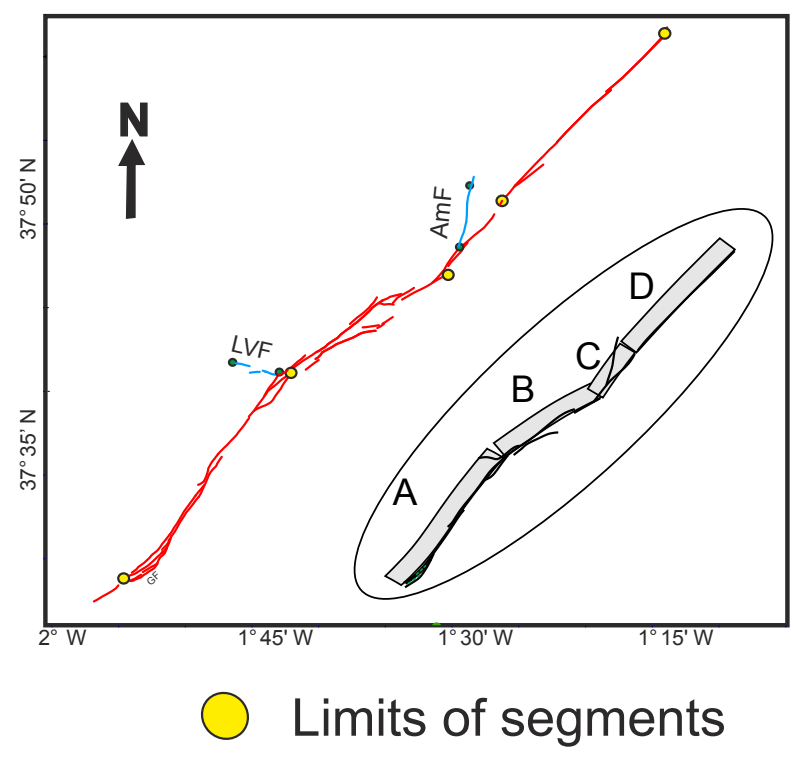

\begin{tabular}{|c|c|c|c|c|}
\hline Segments & $\begin{array}{l}\text { A) Goñar- } \\
\text { Lorca }\end{array}$ & $\begin{array}{l}\text { B) Lorca- } \\
\text { Totana }\end{array}$ & $\begin{array}{l}\text { C)Totana- } \\
\text { Alhama }\end{array}$ & $\begin{array}{l}\text { D) Alhama- } \\
\text { Alcantarilla }\end{array}$ \\
\hline \multicolumn{5}{|l|}{$\begin{array}{l}\text { Geometry and } \\
\text { Kinematics }\end{array}$} \\
\hline $\begin{array}{l}\text { Average Strike }\left({ }^{\circ}\right): \\
\text { Dip }\left({ }^{\circ}:\right. \\
\text { Rake }\left({ }^{\circ}\right): \\
\text { Sense of Movement: } \\
\text { Length }(\mathbf{k m}): \\
\text { Min Depth }(\mathbf{k m}): \\
\text { Max Depth }(\mathbf{k m}): \\
\text { Width }(\mathbf{k m}): \\
\text { Area }\left(\mathbf{k m}^{2}\right):\end{array}$ & $\begin{array}{l}215 \\
70 \\
20 \\
\text { SR } \\
28.0 \\
0 \\
12.0 \\
12.8 \\
357\end{array}$ & $\begin{array}{l}238 \\
70 \\
18-75 \\
R \text { to SR } \\
20.0 . \\
0 \\
12.0 \\
12.8 \\
276\end{array}$ & $\begin{array}{l}221 \\
70 \\
- \\
\text { RS } \\
12.0 . \\
0 \\
12.0 \\
12.8 \\
132\end{array}$ & $\begin{array}{l}225 \\
70 \\
- \\
\text { RS } \\
25.0 \\
0 \\
12.0 \\
12.8 \\
300\end{array}$ \\
\hline \multicolumn{5}{|l|}{$\begin{array}{l}\text { Quaternary } \\
\text { Activity }\end{array}$} \\
\hline $\begin{array}{l}\text { Age of the Youngest } \\
\text { Deposits Affected by } \\
\text { the fault: }\end{array}$ & Holocene & Holocene & $\begin{array}{l}\text { Middle } \\
\text { Pleistocene }\end{array}$ & $\begin{array}{l}\text { Middle } \\
\text { Pleistocene }\end{array}$ \\
\hline $\begin{array}{l}\text { Vertical Slip Rate } \\
(\mathrm{m} / \mathrm{ka} \text { or } \mathrm{mm} / \mathrm{yr}) \text { : }\end{array}$ & 0.200 & 0.16 & - & 0.07 \\
\hline $\begin{array}{l}\text { Horizontal Slip Rate } \\
\text { ( } \mathrm{m} / \mathrm{ka} \text { or } \mathrm{mm} / \mathrm{yr}) \text { : }\end{array}$ & 0.5 & 0.21 & - & - \\
\hline $\begin{array}{l}\text { Net Slip Rate } \\
\text { ( } \mathrm{m} / \mathbf{k a} \text { or } \mathrm{mm} / \mathrm{yr} \text { ): }\end{array}$ & 0.5 & 0.3 & - & 0.07 \\
\hline Maximum earthquake mag. & 7.0 & 6.5 & 5.8 & 6.5 \\
\hline
\end{tabular}

Fig. 9.- Main parameters of fault activity for each segment of the AMF (data collected from: Martínez-Díaz (1999); Masana et al. (2004); García-Mayordomo (2005) and Ortuño et al. (2012). The maximum expected magnitude has been calculated from empirical relationship of Wells and Coopersmith (1994) using surface rupture length and a width value of $12 \mathrm{~km}$.

Fig. 9.- Principales parámetros de actividad de la falla de Alhama de Murcia recopilados a partir de los estudios de: Martínez-Díaz (1999); Masana et al. (2004); García-Mayordomo (2005) y Ortuño et al. (2012). La máxima magnitud esperada ha sido calculada a partir de las relaciones empíricas de Wells and Coopersmith (1994) utilizando la longitud del segmento para una anchura de ruptura de $12 \mathrm{~km}$.

Focal mechanisms for the Lorca 2011 earthquake present a nodal plane sub parallel to the AMF, dipping to the north (Fig. 8). The aftershocks registered until the $7^{\text {th }}$ July where relocated with a dense seismic station network by López-Comino et al. (2012). They are aligned parallel to the AMF and they are concentrated to the north of the intersegment zone, suggesting that the source of the earthquake is a fault parallel to the AMF dipping to the north as proposed in a preliminary study by Vissers and Meijninjer (2011). Martínez-Díaz et al. (2012) using InSAR measurements of the coseismic deformation to better define the earthquake source parameters confirmed that this earthquake was produced by the rupture of an area of $\sim 4$ by $3 \mathrm{~km}$ within the complex structure that limits the Goñar-Lorca and Lorca-Totana segments of the AMF (Fig. 8).

The kinematic and seismotectonic characteristics of the Lorca 2011 earthquake and the low relief produced by the long term activity of the FAM in the intersegment region of Lorca are consistent with a deformation that is accommodated in a distributed mode by slip of several structures with different orientations (sources of small earthquakes, like Lorca and its aftershocks), preventing the building of relief. More paleoseismic data along the AMF, specifically in the intersegment section of the fault, are needed to know if this region would act as a barrier only for small - moderate earthquakes $(\mathrm{Mw}<7)$, but less frequent and larger earthquakes $(\mathrm{Mw}>7)$ would be capable of propagating through the intersegment zone, rupturing both segments. This possibility is discussed by Ortuño et al. (2012) on the basis of the paleoseismic data available for the larger fault segments.

\section{Discussion and conclusions: Seismic potential and seismic hazard}

\subsection{Implications of the structure of the AMF in the seismotectonic behavior}

The AMF structure and its position relative to nearby active faults should be taken into account to understand the present seismotectonic activity. With regard to the local dynamic setting, the interference of the AMF with the Palomares and Carrascoy faults could be playing an important role in the control of the local stress field driving the activity of the AMF. The activity of the Palomares fault could be producing a local rotation of the Shmax that could enhance the strike slip movement on the AMF 
(Martínez-Díaz, 1999; 2002). To the east the activity of the Carrascoy Fault seems to absorb an important part of the NNW-SSE shortening. This could explain the lower slip rate in the Alhama-Alcantarilla segment.

The interpretation of the paleoseismic data obtained in the AMF is also conditioned by the fault structure. In the northern section of the GL segment and in the TA and AA segments, most of the deformation is concentrated in a single fault zone dipping NW (Fig. 4). However, no paleoseismic data are available in these sections to be compared with the segments dominated by two or more branches. Only two paleoseismic studies have focused on the AMF traces bounding the mountain fronts. These works identified deformations affecting travertine deposits overlapping the northern branch of the AMF at the LT segment (north-AMF; NAMF in Fig. 4) that provided $\sim 0.08 \mathrm{~mm} / \mathrm{y}$ Quaternary vertical slip rates (MartínezDíaz and Hernández-Enrile, 2001; Silva et al. 2007). No paleoseismic excavations in these northern faults have been carried out so far. This is due to the high rate of erosion, which prevents the preservation of recent deposits on the fault zone. Nevertheless, detailed analysis of the morphology suggests that these faults clearly affect the Pleistocene alluvial fans and recent, probably Holocene, fluvial channels with horizontal and vertical movements.

In the fault branched segments at the GL and LT the younger deposits are affected by antithetic faults. These south-dipping faults are interpreted as faults that accommodate at shallow levels the uplift produced by a synthetic branch of the AMF (the SAMF) that in some places (the Goñar site) has not yet reached the surface (Martínez-Díaz et al., 2012; Ortuño et al., 2012) (see cross sections 1 and 3 in Fig. 4). This uplift combined with the strike slip transpressive regime favors the formation of flower like structures and produce the uplifting and folding of an elongated block within the depression.

According to this interpretation, the coseismic deformation observed in the antithetic faults should be considered as part of the activity of the AMF and should be added to the deformation of the northern branches limiting the mountain fronts. However, no geophysical data exist that allow us to deny the possibility that the antithetic faults are newly formed faults disconnected from the AMF at depth. In this line, Martínez-Díaz (1999) described that the activity of the southern branch of the AMF in the Lorca-Totana segment (SAMF in Fig. 4) may be younger than the activity in the northern branch. The SAMF controlled the position of the late Messinian coast and fluvial channels are more affected by the movement of this branch. An interesting working hypothesis is that the formation of these antithetic faults could be related to the regional geodynamics changes as the proposed counter- clockwise rotation of the Nubia-Eurasia convergence in the last 3 My along the Mediterranean collision, accompanied by convergence rates decreased by roughly $25 \%$ (Calais et al. 2003). This change could have produced an increase of the reverse strain regime and the formation of new better oriented faults in the Lorca-Totana and the Goñar area.

Finally, the geometry of the AMF suggests that secondary faults as Las Viñas and Amarguillo faults appear to control the segmentation of the AMF. Furthermore, their activity must be taken into account since they can induce static stress transfers that influence the stability of the AMF.

\subsection{Fault activity parameters and implications for seismic hazard}

Values of maximum magnitude obtained from the Quaternary paleoseismicity are consistent with the theoretical magnitudes obtained from the segment sizes using empirical relationships (table 1). However, slip rates obtained from the paleoseismicity are lower than those obtained from long-term geological data. This difference could be explained by: (a) an incomplete quantification of the recent fault activity caused by the possible existence of aseismic deformation that is difficult to be identified in paleoseismic analysis. Some studies focusing on the rheology of the fault gouge of the AMF suggest that, at least in some sections of the fault, the slip may be dominated by aseismic creep driven by a clay rich "fault gouge" (Rutter et al., 1986; Rodríguez Escudero et al. (2012); (b) the sedimentary record of paleoearthquakes is probably incomplete, i.e, not all the paleoearthquakes produced by the fault have been identified by the paleoseismic studies. The deformation generated by the fault zone is probably distributed in several branches that might not to move simultaneously in each seismic event. (c) The decrease of convergence rate and the rotation of the Nubia-Eurasia relative movement during the Quaternary proposed in geodynamic models would induce a decrease in the AMF activity.

The $11^{\text {th }}$ May 2011 Lorca earthquake evidenced that moderate events (Mw 5.0 - 5.5) may be highly destructive if they occur close to populated areas. In the AMF the intersegment areas coincide with depressed regions located between ranges (Fig. 6). These areas are natural passes for the large rivers flowing towards the Guadalentín Valley, and they have traditionally been preferred sites for the settlement of towns (i. e. Lorca, Totana, Alhama, Alcantarilla). The study of the moderate Mw 5.05.5 earthquakes in these areas will be very important for the local seismic hazard studies. 
In the figure 9 we propose the seismic sources that may be defined from the analysis presented in this work. The activity parameters values, proposed for each source, are also shown. These values are the best constraints for the AMF behaviour that we have so far in order to be utilized in seismic hazard analysis.

From the information provided by the structure of the $\mathrm{AMF}$ and the previous neotectonic and paleoseismic studies it is evident the need for new data to accomplish a better understanding of existing paleoseismic data and those obtained in the future. This underlines the necessity for: (a) geophysical surveys to determine the geometry at depth of the antithetic faults of the AMF and the distribution of deformation in the intersegment areas; (b) searching for paleoseismic evidences on the faults of the AMF limiting the main mountain, with special attention to the recent slip rates that might provide the study of vertically and horizontally displaced channels; (c) rheological and microtectonic analysis of fault rocks along the AMF to identify possible aseismic slip mechanisms that are capable of generating structures that may be misinterpreted.

\section{Aknowledgments}

This research Project was funded by the Universidad Complutense de Madrid Project TECTACT GR35/10A-910368 and by RISKNAT. We received financial support of Spanish projects CGL2008-01830, GEOTACTICA: CGL2009-14405-C0202-BTE; EVENT (CGL2006-12861-C02-01/BTE), SHAKE (CGL201130005-C02-01/BTE) and the Consolider-Ingenio 2010 program, under CSD2006-0004 "Topo-Iberia". We thank Dr. R. Perez-López and Dr. J. M. Insua-Arevalo for their constructive revisions that helped to improve the quality of this paper.

\section{References}

Aldaya, F., Álvarez, F., Galindo-Zaldívar, J., González-Lodeiro, F., Jabaloy, A., Navarro-Vilá, A. (1991): The Maláguide-Alpujárride contact (Bétic Cordilleras, Spain): a brittle extensional detachment. Compte Rendu Acad Sci Paris 313, 1447-1453.

Armijo, R. (1977): La zona des failles Lorca-Totana (Cordillères Bétiques, Espagne). Étude tectonique et neotectonique. Thèse Illème cycle, Univ. Paris VII: 229 p.

Balanyá J.C., García-Dueñas, V. (1987): Les directions structurales dans le Domaine d'Alboran de part de d'autre du détroit de Gibraltar. Compte Rendu Acad Sci Paris 304, 929-933.

Bousquet, J.C. (1979): Quaternary strike-slip faults in southeastern Spain. Tectonophysics 52, 277-286. doi:10.1016/00401951(79)90232-4.

Bousquet, J.C., Phillip, H. (1976a): Observations micro-tectoniques sur la distension plio-pleistocene ancien dans l'est des Cordillères Bétiques (Espagne meridionale). Cuad. Géol. 7, 57-67.
Bousquet, J.C., Phillip, H. (1976b): Observations micro-tectoniques sur la compresion nord-sud quaternaire des Cordillères Betiques Orientales (Espagne Méridional - Arc de Gibraltar). Bull. Soc. Géol. France 18, 711-724.

Bull, W. B., McFadden, L. (1977): Tectonic geomorphology North and South of the Garlock fault, California. In: Dohering, D. O. (ed.), Geomorphology in Arid Regions. Publ. in Geomorphology, State University of New York, Binghamton: 115-138.

Calais, E., DeMets, C. Nocquet, J-M. (2003): Evidence for a post3.16-Ma change in Nubia-Eurasia-North America plate motions? Earth and Planetary Science Letters 216, 81-92 doi: 10.1016/ S0012-821X(03)00482-5.

Crowell, J.C., Sylvester, A.G. (1979): Introduction to the San Andreas-Salton Trough juncture. In: Crowell, J.C. and Sylvester, A.G. (eds.), Tectonics of the Juncture Between the San Andreas Fault System and the Slaton Trough, South-Eastern California. A Guidebook. University of California, Santa Barbara: 1-13.

DeMets, C., Gordon, R. G., Argus, D. F., Stein, S. (1994): Effect of recent revisions to the geomagnetic reversal time scale on estimates of current plate motions, Geophys. Res. Lett. 21, 2191-2194. doi:10.1029/94GL02118.

Egeler, C., Simon, O. J. (1969): Sur la tectonique de la Zone Bétique (Cordillères Bétiques, Espagne). Verhandelingen der Koninklijke Nederlandse Akademie van Weten-schappen 25, 90 p.

Faulkner, D.R. (1997): The role of clay-bearing fault gouges in controlling fluid pressures in fault zones: implications for fault mechanics, PhD thesis, University of Manchester. 279p.

Galindo-Zaldívar, J., González-Lodeiro, F., Jabaloy, A. (1989): Progressive extensional shear structures in a detachment contact in the western Sierra Nevada (Betic Cordilleras, Spain). Geodinamica Acta 3, 73-85.

García-Dueñas, V., Balanyá, J.C., Martínez-Martínez, J.M. (1992): Miocene extensional detachments in the outcropping basement of the northern Alborán Basin (Betics) and their tectonic implications. GeoMarine Letters 12, 88-95. doi: 10.1007/BF02084917.

García Mayordomo, J. (2005): Caracterización y análisis de la peligrosidad sísmica en el sureste de España. PhD Thesis, Universidad Complutense, $373 \mathrm{p}$.

García-Meléndez, E., Goy, J.L., Zazo, C. (2003): Neotectonica and Plio-Quaternary landscape development within the eastern HuércalOvera Basin (Betic Cordilleras, southeastern Spain). Geomorphology 50, 111-133. doi:10.1016/S0169-555X(02)00210-6.

García-Meléndez, E., Goy, J.L., Zazo, C. (2004): Quaternary tectonic activity in the Huércal-Overa Basin (Almería Southeast Spain): deformations associated with the Albox fault. Geogaceta 36, 63-66.

Gauyau, F., Bayer, R., Bousquet, J. C., Lachaud, J. C., Lesquer, A., Montenat, C. (1977): Le prolongement de l'accident d'Alhama de Murcia entre Murcia et al.icante (Espagne meridionale). Bull. Soc. Geol. France 7, 623-629.

Harvey, A.M. (1990): Factors influencing Quaternary alluvial fan development in Southeast Spain. In: Rachocki, A.H., Church,U. (eds.), Alluvial Fans: A Field Approach. Wiley, Chichester, 247- 269.

Herráiz, M., Mezcua, J. (1979): Aplicación del análisis espectral al sismo de Lorca del 6 de junio de 1977. Determinación de los parámetros focales. III Asamblea Nacional de Geodesia y Geofísica, Instituto Geográfico Nacional, Madrid: 395-417.

Instituto Andaluz de Geofísica (IAG) (2011): Terremoto Lorca (11 Mayo 2011). Estudios preliminares, Granada, Spain. [Available at http://www.ugr.es/iag.]

Instituto Geográfico Nacional (IGN) (2011): Serie terremoto NE Lorca (Murcia), Madrid. [Available at http://www.ign.es.]

Instituto Geológico y Minero de España (IGME) (2011): Informe Geológico Preliminar del Terremoto de Lorca del 11 de Mayo del año 
2011, 5.1 Mw, Madrid. [Available at http://www.igme.es.]

Insua-Arévalo, J.M., García-Mayordomo, J., Salazar, A., RodríguezEscudero, E., Martínez-Díaz, J.J., Álvarez-Gómez, J.A., Canora, C., Martín-Banda, R., Pérez-López, R., Rodríguez-Pascua, M.A. (2012): Actividad holocena de la Falla de Carrascoy, Murcia. Resultados preliminares de un análisis paleosísmico. Geo-Temas (in press).

Jiménez-Munt I., Negredo, A.M. (2003): Neotectonic modelling of the Africa-Eurasia plate boundary from the Mid-Atlantic ridge to Algeria, Earth. Planet. Sci. Lett. 205, 257-271. doi: 10.1016/S0012$821 X(02) 01045-2$.

Jiménez-Munt, I., Sabadini, R., Gardi, A. (2003): Active deformation in the Mediterranean from Gibraltar to Anatolia inferred from numerical modeling and geodetic and seismological data. Journal of Geophysical Research 108. doi:10.1029/2001JB001544.

Jabaloy, A.J., Galindo-Zaldívar, J., González-Lodeiro, F. (1993): The Alpujárride-Nevado-Filábride extensional shear zone. Betic Cordillera, SE Spain. Journal of Structural Geology 15, 555-569. doi 10.1016/0191-8141(93)90148-4.

Khazaradze, G., Gárate, J., Suriñach, E., Davila, J.M., Asensio, E. (2008): Crustal deformation in south-eastern Betics from CuaTeNeo GPS network. Geo-Temas 10, 1023-1026.

Koulali, A., Ouazar, D., Tahayt, A., King, R.W., Vernant, P., Reilinger, R.E., McClusky, S., Mourabit, T., Davila, J.M., Amraoui, N. (2011): New GPS constraints on active deformation along the Africa-Iberia plate boundary. Earth and Planetary Science Letters 308, 211-217. doi: 10.1016/j.eps1.2011.05.048.

Lopez-Comino, J.A., Mancilla, F. Morales, J. Stich, D. (2012): Rupture directivity of the 2011, Mw 5.2 Lorca earthquake (Spain). Geophysical Research Letters 39, L03301. doi:10.1029/2011GL050498.

Martínez-Díaz, J. J. (1998). Neotectonica y Tectonica Activa del Oeste de Murcia y sur de Almeria (Cordillera Betica). PhD Thesis, Universidad Complutense Madrid: 470 p.

Martínez-Díaz, J. J. (2002): Stress field variety related to fault interaction in a reverse oblique-slip fault: the Alhama de Murcia fault, Betic cordillera, Spain. Tectonophysics 356, 291-305. doi: 10.1016/ S0040-1951(02)00400-6.

Martínez-Díaz, J.J., Masana, E., Hernández-Enrile, J.L., Santanach, P. (2001): Evidence for coseismic events of recurrent prehistoric deformation along the Alhama de Murcia fault, southeastern Spain. Acta Geológica Hispánica 36, 315-327.

Martínez-Díaz, J.J., Hernández-Enrile, J.L. (2001): Using Travertine Deformations To Characterize Paleoseismic Activity on an active oblique-slip fault. Geologica Acta 36, 297-313.

Martínez-Díaz, J.J., Bejar-Pizarro, M., Álvarez-Gómez, J.A., Mancilla, F., Stich, D., Herrera, G., Morales, J. (2012): Tectonic and seismic implications of an intersegment rupture. The damaging May 11th $2011 \mathrm{Mw} 5.2$ Lorca, Spain, earthquake, Tectonophysics. doi:10.1016/j.tecto.2012.04.010.

Martínez-Martínez, J.M., Azañón, J.M. (1997): Mode of extensional tectonics in the southeastern Betics (SE Spain): implications for the tectonic evolution of the peri-Alborán orogenic system. Tectonics 16, 205-225._doi: 10.1029/97TC0015.

Masana, E., Martínez-Díaz, J.J., Hernández-Enrile, J.L., Santanach, P. (2004): The Alhama de Murcia fault (SE Spain), a seismogenic fault in a diffuse plate boundary. Seismotectonic implications for the Ibero-Magrebian region. Journal of Geophysical Research 109, 1-17._doi:10.1029/2002JB002359.

Masana, E., Pallàs, R., Perea, H., Ortuño, M., Martínez-Díaz, J.J., García-Meléndez, E., Santanach, P. (2005): Large Holocene morphogenic earthquakes along the Albox fault, Betic Cordillera, Spain. Journal of Geodynamics 40, 119-133. doi:10.1016/j. jog.2005.07.002.
Masana, E., Gracia, E., Martínez-Díaz. J.J., Moreno, X., Ortuno, M., Perea, H., Khazaradze, G., Pallas, R. Rodes, A., Queralt, P., Coll, M., Bartolome, R., Garcia-Melendez, E., Ruano, P., Stepancikova, P., Dañobeitia, J.J., Santanach, P. (2010): characterizing the seismic potential of the Eastern Betic Shear Zone (EBSZ), a major source of earthquakes in southeastern Iberia. In: J.M. Insua and F. Martín-González (eds.), Contribución de la Geología al Análisis de la Peligrosidad Sísmica, Sigüenza (Guadalajara, España): 101-105.

Meghraoui, M., Cisternas, A., Philip, H. (1986): Seismotectonics of the Cheli basin: Structural background of the El Asnam earthquake. Tectonics 5, 809-836._doi:10.1029/TC005i006p00809.

Meijninger, B.M.L. (2006): Late-orogenic extension and strike-slip deformation in the Neogene of southeastern Spain. PhD Thesis, Universiteit Utrecht. Geologica Ultraiectina 269, 179 p.

Montenat, C., Ott D'Estevou, P. Masse, P. (1987): Tectonic-sedimentary characters of the Betic Neogene Bassins evolving in a crustal transcurrent shear zone (SE Spain). Bull. Centres Rech. Explo. Prod. Elf Aquitaine. 11, 1-22.

Montenat, C., Ott D’Estevou, P., Aellen, M., La Chappelle, G. (1990): Les series néogènes entre Lorca et Huercal Overa. Documents et Travaux de l'IGAL, 12-13, 281-286.

Ortuño, M., Masana, E., García-Meléndez, E., Martínez-Díaz, J.J., Štěpančíková,P., Cunha, P., Sohbati, R., Canora, C., Buylaert, J.P., Murray, A-S. (2012): An exceptionally long paleoseismic record of a slow-moving fault: the Alhama de Murcia fault (Eastern Betic Shear Zone, Spain). Geological Society of America Bulletin (in press). doi: 10.1130/B30558.1.

Ott d'Estevou, P., Montenat, C. (1985): Evolution structurale de la zone Betique orientale (Espagne) du Tortonian à l' Holocène C.R. Acad. Sci. Paris 300, 363-368.

Rodríguez-Escudero E, Martínez-Díaz JJ, Tsige M. (2012): Deformaciones dúctiles en régimen frágil en una falla activa lenta: La falla de Alhama de Murcia. Implicaciones sismotectónicas. GeoTEMAS (in press).

Rutter, E. H., Maddock, R. H., Hall, S. H., White, S. H. (1986): Comparative microstructures of natural and experi-mentally produced clay-bearing fault gouges. In: International Structure of Fault Zones (Ed. By Y. Wang-Chi), Pure Appl. Geophys. 124, 3-30. doi: 10.1007/BF00875717.

Serpelloni, E., Vannucci, G., Pondrelli, S., Argnani, A., Casula, A., Anzidei, M., Balde, P., Gasperini, P. (2007): Kinematics of the Western Africa-Eurasia plate boundary from focal mechanisms and GPS data. Geophysical Journal Internacional 169, 1180-1200. doi: 10.1111/j.1365-246X.2007.03367.x.

Silva, P.G. (1994): Evolución geodinámica de la Depresión del Guadalentín desde Mioceno Superior hasta la actualidad: Neotectónica y Geomorfología, Ph.D. Thesis. Universidad Complutense Madrid: 642 p.

Silva, P., Goy, J.L., Zazo, C. (1992a): Características estructurales y geométricas de la falla de desgarre de Lorca-Alhama. Geogaceta 12, 7-10.

Silva, P., Goy, J.L., Zazo, C. (1992b). El corredor de desgarre del Guadalentín: Génesis y evolución geomorfológica y tectónica de frentes montañosos, y abanicos aluviales. In: Lopez Bermúdez, Conesa and Romero (eds.), II Reunión Nacional de Geomorfología. Estudios de Geomorfología de España. S. E. G., Murcia: 770-774.

Silva, P. G., Goy, J. L. Somoza, L., Zazo, C., Bardaji, T. (1993): Landscape response to strike-slip faulting linked to collisional settings: Quaternary tectonics and basin formation in the Eastern Betics, southeastern Spain. Tectonophysics 224, 289-303. doi: 10.1016/0040-1951(93)90034-H.

Silva, P.G., Goy, J.L., Zazo, C., Lario, J., Bardají, T. (1997): Palaeoseismic indications along "aseismic" fault segments in the Guad- 
alentín Depression (SE Spain). Journal of Geodynamics 24, $105-$ 115. doi:10.1016/S0264-3707(97)00011-2.

Soler, R., Masana, E., Santanach, P. (2003): Evidencias geomorfológicas y estructurales del levantamiento tectónico reciente en la terminación sudoccidental de la falla de Alhama de Murcia (Cordillera Bética Oriental). Revista de la Sociedad Geológica de España 16, 123-133.

Stich, D., Ammon, C.J., Morales, J. (2003): Moment tensor solutions for small and moderate earthquakes in the IberoMaghreb region. Journal of Geophysical Research 108, 2148, doi:10.1029/2002JB002057.
Vissers, R.L.M, Meijninger, B. M. L. (2011): The 11 May 2011 earthquake at Lorca (SE Spain) viewed in a structural-tectonic context. Solid Earth 2, 199-204._doi:10.5194/se-2-199-2011.

Wells, D.L., Coppersmith, K.J. (1994): New Empirical Relationships among Magnitude, Rupture Length, Rupture Width, Rupture Area, and Surface Displacement. Bulletin of the Seismological Society of America 84, 974-1002. 